\title{
Cytogenetic effect of some nanostructure polymers prepared via gamma irradiation on Vicia faba plant
}

\author{
M. Salah', Soad Yehia ${ }^{1}$ and Rania T. Ali ${ }^{2}$ (1)
}

\begin{abstract}
Background Nourishment plants during the field time is a must; to have healthy, high productive and self-propagating plants. The trendy nano-fertilizers came to the front in modernized agriculture seeking for minimizing the soil suffocation with other chemical fertilizers in the bulk size. Nano-fertilizers may represent a way out of shot as they are completely absorbed by plant due to their small size, also it magnifies the benefit to the plant due to its high surface area. Nano-fertilizers are introduced via different way of synthesis methods. In this work, three of new nanocomposites are prepared in nano form via Gamma irradiation from Cobalt 60 source at irradiation dose 5 KGy. These composites which can supply plants with P, Zn elements needs to be revised for their safety usage in agriculture.

Methodology Three compounds; Zinc oxide, phosphorous and the mixed Zinc-phosphorous elements were prepared in nano-composite forms coated with PVP as a shell and then characterized by HR-TEM, UV and FT-IR to emphasize their new sizes and shapes, then, they were examined for their cytotoxicity in three concentrations $(0.5,1$ and 2\%) on Vicia faba plants; after $3 \mathrm{~h}$ of direct roots treatment. Cytotoxicity test concerned the mitotic index, phase index, abnormal mitosis and the type of the aberrations at each phase.
\end{abstract}

Results The three tested NPs exerted mito-accelerating effect on root meristematic cells. However, concentrationdependent genotoxicity was also an evident.

Conclusion The three examined nano-composites may recommend to be used in the lowest examined concentrations to minimize its harm effect on the plant cell and keep their benefits to the environment. It also recommended to count the Zn/P mix NPs over ZN or P separately as it induces an intermediating cytogenetic effect on mitosis apparatus of Vicia faba plant.

Keywords Nanoparticles, HR-TEM, FT-IR, Mitosis and cytogenetic

\section{${ }^{*}$ Correspondence:}

Rania T. Ali

raniatawfick@hotmail.com

Full list of author information is available at the end of the article permitted by statutory regulation or exceeds the permitted use, you will need to obtain permission directly from the copyright holder. To view a copy of this licence, visit http://creativecommons.org/licenses/by/4.0/. The Creative Commons Public Domain Dedication waiver (http://creativecommons.org/publicdomain/zero/1.0/) applies to the data made available in this article, unless otherwise stated in a credit line to the data. 


\section{Graphical Abstract}

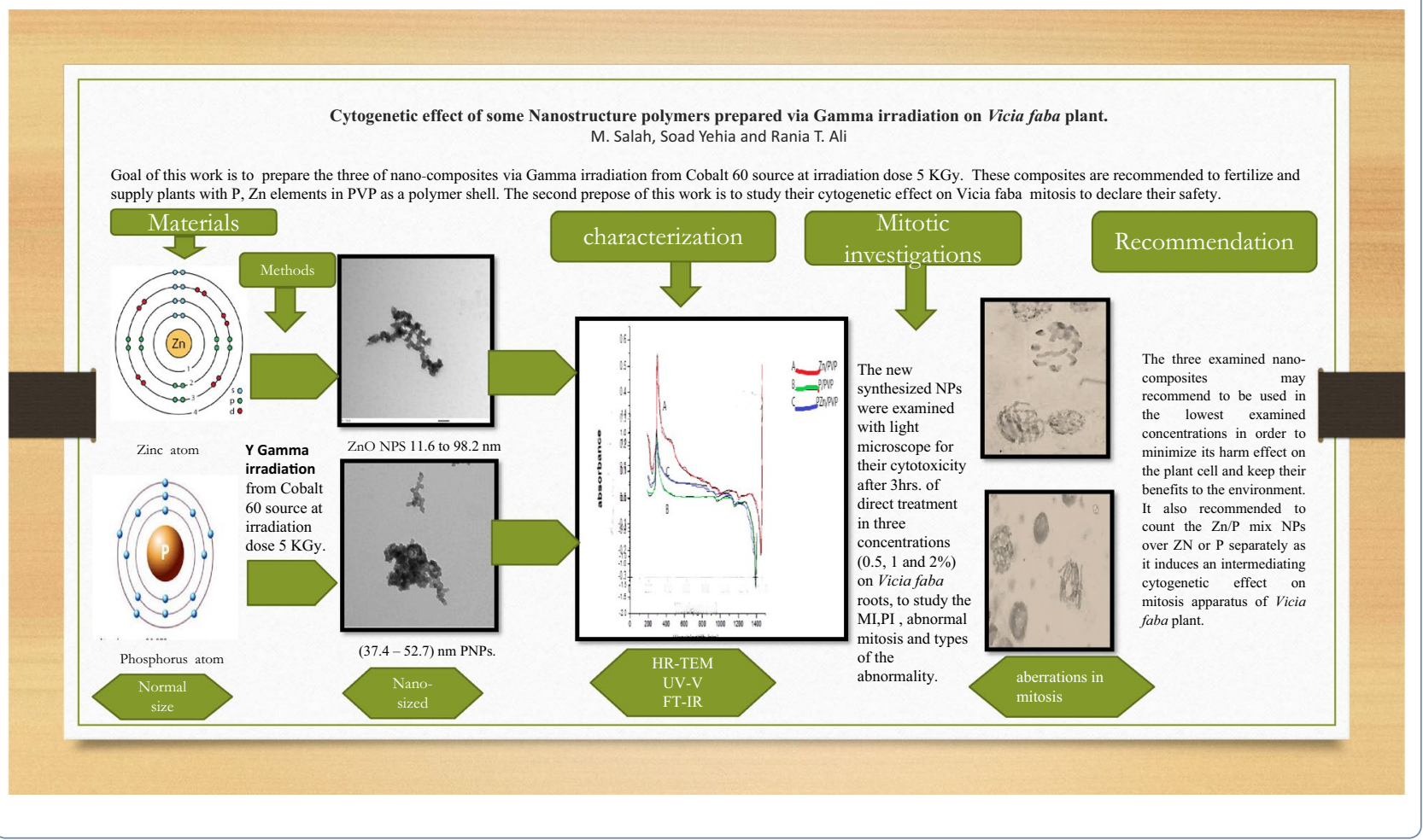

\section{Background}

Zinc $(\mathrm{Zn})$ is very important element to human, animal and plants. Deficiency in Zinc in human causes dwarfism, affect blood coagulation, and wound remedying, skin deformations, cell-mediated immune dysfunction, cognitive impairment and other problems[1], it is a component of thousands of functional proteins [2]. $\mathrm{Zn}$ is also an essential micro-element required for agriculture to improve the plant growth, health and productivity. $\mathrm{Zn}^{2+}$ also help in the growth hormone (auxin) formation, help in grain formation and promotes maturity. In poor soil with low or without $\mathrm{Zn}$ the plants suffer and show symptoms, such as chlorosis and abnormal rooting. Based upon this; modification of some plants such as rice and wheat to accumulate zinc in its grain through application of $\mathrm{Zn}$ fertilizers is double benefit goal to human to ensure safe health growth [3]; and to plant to ensure high quality plants [4]. Many forms of $\mathrm{Zn}$ fertilizers are available in market, since Forties of this century, such as $\mathrm{Zn}$ sulfate, $\mathrm{Zn}$ oxide and $\mathrm{Zn}$ carbonate. However, here, we warn the danger of $\mathrm{Zn}$ accumulation which may pollute the soil, underground water and irrigation canals which in turn may affect the eco-system of the planet earth.

It worth to mention that, fertilizers rich in $\mathrm{Zn}$ should be added and mixed with $\mathrm{P}$ enrich fertilizer for plant benefit and for keeping the P/ZN balance as phosphorous influences the $\mathrm{Zn}$ uptake by plant.

phosphorous $(\mathrm{P})$ element is one of the essential nutrients required for all metabolic processes in planted crops, such as energy transfer, signal transduction, enzyme catalysis, biosynthesis of DNA; RNA; lipids and proteins, cell division, seeds formation and grain maturity, as well as photosynthetic pigments and biochemical changes. In poor soil with insufficient phosphorous; plants suffer and shows symptoms, such as growth retardation, abnormally dark green or reddish-purple color along the edge of the lower plant leaves and thick cuticle [5]. In past decades, $P$ enrich-fertilizers have enormously used, such as rock phosphate, phosphoric acid, calcium orthophosphates, ammonium phosphates, ammonium polyphosphate and nitric phosphates. However, the excessive production, conservation and usage of $\mathrm{P}$ causes serious effects to the environment, including soil acidification, and water pollution [6], Phosphorus uptake from plants is mainly hindered due to its scarce solubility in water which limits phosphate mobility and prevents phosphate from being absorbed by the root hairs to do the crops nutrition in time of need [7].

Nanotechnology may offer the solution to this issue as effective alternatives to traditional fertilizers have proved 
to enhance the growth of plants $[8,9]$. Production of nano-fertilizers spared farmers the changing of soil texture or contaminate the soil with accumulative elements and minimize the environmental pollution risk [10].

At present, nanomaterials are widely used in the field of agriculture to enhance the productivity of crops, enhance the plant performance under abiotic stress, such as drought [11] to protect them from pathogens [12-14]. In addition, literature reviews have suggested that, the application nanomaterials in low dose can stimulate the seed germination as well as growth rate in different crop plants $[15,16]$. The success of nano-fertilizers is due to the very small sized particles which can be easily absorbed with the plant's roots; also due to the high surface area which magnify its benefits as it facilitates the sorption efficiency of plants.

Preparation of nanoparticles means production of small sized particles with preferable character at the dimension below $100 \mathrm{~nm}$, thus it may be carried out through chemical or physical synthesis methods. Among physical synthesis methods for nano-metals preparations is Gamma radiation method [17].

Gamma radiation method have advantage over other physical methods, because it is cheap, reproducible, may control the shape of the particles yields monodisperse metallic nanoparticles, easy, and use less toxins precursors: in water or solvents, such as ethanol, it uses the least number of reagents, it uses a reaction temperature close to room temperature with as few synthetic steps as possible (one-pot reaction) and minimizing the quantities of generated by-products and waste [18].

Among the most common combinations metallic NP and polymeric coats are: $\mathrm{Ag}$ [19], $\mathrm{Cu}$ [20], $\mathrm{ZnO}$ [21, 22]; as metallic nuclei and PVA, PANI, poly ( $\mathrm{N}$-isopropyl acrylamide) (PNIPAm) as a polymer shell.

Polyvinylpyrrolidone (PVP) is non-toxic polymer with functional groups; $\mathrm{C}-\mathrm{N}, \mathrm{CH} 2$ and $\mathrm{C}=\mathrm{O}$ which can hydrogen bond solvent molecules. PVP is soluble in both water and organic solvents as a result of the highly polar amide group within the pyrrolidone ring and a polar methylene and methine groups in the ring and along its backbone. Its solubility renders it is an excellent phase transfer agent, while its biocompatibility is enabling application of PVP-capped nanomaterials in nanomedicine applications. It also used in nano-metal fertilizers production as a surfactant, great stabilizer, reducing agent shape, controlling agent and preventing the aggregation of NPs via the repulsive forces arises from its carbon chain. Moreover, the ability of PVP to passivate surfaces of metal chalcogenide NPs minimizes defects and improves the photoluminescent properties of such materials. PVP is considered as a mild reductant due to the hydroxyl groups which terminate it molecules [19].
However, nanotechnology based fertilizes must have its direct effect on plants through the inter action between them; this effect may be beneficial or adverse. For example, [22] pointed to the oxidative effect of $\mathrm{ZnO}$ nanoparticles on Brassica napus L. Therefore, NPs as fertilizers must be studied very well to declare its safety in doses; to avoid their toxicity, accumulation or any adverse effect in plant systems as a previous step before commercialization.

In this work, Zinc and Phosphorus are used as metallic and non-metallic nuclei and the PVP as a polymer coat or shell are synthesized and introduced as new fertilizers (zinc sulphate, phosphoric acid and $\mathrm{Zn}$ sulphate/phosphoric) in nano forms; they are synthesized via gamma irradiation; they need to be examined in three concentrations $0.5,1$ and $2 \%$ for their cytotoxicity and genotoxicity on faba plant after main roots treatment for $3 \mathrm{~h}$ of treatment.

\section{Materials and methods}

This designed experiment was carried out in two successive steps as follows:

(1) Preparation of the three examined fertilizers in nano-particles forms via Gamma irradiation method which took place in the National center for radiation research and technology, Egypt.

(2) To study the effect of the prepared nano-products on the mitosis apparatus of Vica faba root tip meristems which took place on bench top in cytology and cytogenetics lab, National Research Centre, Egypt.

\section{Materials for nano-particles preparation}

Orthophosphoric acid (85\%) H3PO4 (M. W. 98) obtained from Alpha Chemika. Polyvinylpyrrolidone (PVP) powder, COSMOROL ${ }^{\mathrm{TM}}$ K30-CISME Italy. Zinc sulphate.7 $\mathrm{H}_{2} \mathrm{O}$ and Glycerine USP 99.5\% obtained from El-Gomhouria Co., Egypt.

\section{Materials for the cyto-genecity experiment}

Biomaterials: The Vicia faba $(2 \mathrm{n}=12)$ (Var. Giza 716); were obtained from the Crop Research Institute, ARC, Giza, Egypt.

Chemicals: Carnoy's fixative solution: 3 parts of absolute ethyl alcohol: I part of glacial acetic acid. Fuchsine dye for microscopically examination.

\section{Preparations and characterization of nanoparticles Preparations}

Preparation of PVP/zinc nanoparticles (Zn NPs) $1 \%$ $(\mathrm{w} / \mathrm{v})$ of PVP powder was dissolved in bi-distilled water 
then $10 \%$ of zinc sulfate salt was also added and stirring via magnetic stirrer at $70{ }^{\circ} \mathrm{C}$ for $30 \mathrm{~min}$. The mixture was poured into test tubes then irradiated with gamma rays from Cobalt 60 source at irradiation dose $5 \mathrm{kGy}$. [23, 24].

Preparation of $P V P /$ phosphorous nanoparticles (P NPs) $18 \%(\mathrm{v} / \mathrm{v})$ of phosphoric acid was added to an equivalent amount of distilled water then add 1\% (w/v) PVP powder via continuous stirring at $70{ }^{\circ} \mathrm{C}$.Finally, after full mixing of the added components, $18 \%(\mathrm{v} / \mathrm{v})$ of glycerol was added during stirring for nearly $45 \mathrm{~min}$. The resulted solution was exposed to gamma radiation dose at $5 \mathrm{kGy}$.

Preparation of $Z n / P$ nanoparticles (Zn/P NPs) $\quad 18 \%(\mathrm{v} / \mathrm{v})$ of phosphoric acid was added to an equivalent amount of bi-distilled water. In addition, $1 \%(w / v)$ Polyvinylpyrrolidone (PVP) powder was added via continuous stirring at $70{ }^{\circ} \mathrm{C}$. After dissolving of PVP, an equivalent amount of $18 \%(\mathrm{v} / \mathrm{v})$ Glycerin (glycerol) was added. Finally, after full mixing of the components, $10 \%(\mathrm{w} / \mathrm{w})$ of zinc sulfate was added to solution with the continued stirring. The resulted solution was exposed to gamma radiation dose at $5 \mathrm{kGy}$. The dose rate was $1 \mathrm{~Gy} / 14.4 \mathrm{~s}$.

\section{Characterization}

Nanoparticle tracking analysis took place by High Resolution Transmission electron microscopy (HR-TEM) that uses; both the transmitted and the scattered beams to create an interference image in higher magnification by which we can resolve atom by atom. It also produces an image from electrons deflected by a particular crystal plane.

HR-TEM measurements were performed with (JEOL, JEM 2100, Japan) operating at $200 \mathrm{kV}$. The magnification of images is X15000.

The UV-V is a reliable tool to evaluate the desired optical properties of nanofillers in a polymer matrix. The absorption spectra were taken by double beam spectrophotometer provided with computer data acquisition Type JASCO 670UV-Vis/NIR.

FT-IR spectroscopy has been used in both qualitative and quantitative analysis of nanofillers and their nanocomposites. The analysis was carried out using FT-IR 6300 , Jasco, Japan in the range $400-4000 \mathrm{~cm}^{-1}$.

\section{Experiment scenario cytological studies}

Vicia faba seeds with homogenous color and size were water soaked for $24 \mathrm{~h}$, then germinated on filter paper rolls at room temperature, when the main roots reached about $2 \mathrm{~cm}$ length ( 4-day-old seedling) they were soaked for $3 \mathrm{~h}$ with different concentration $(0.5,1$ and $2 \%)$ of three prepared nanostructure polymers "PVP $+\mathrm{ZnSO}_{4}$ ", "PVP + glycerol $+\mathrm{H}_{3} \mathrm{PO}_{4}$ " and
"PVP + Glycerol $+\mathrm{ZnSO}_{4}+\mathrm{H}_{3} \mathrm{PO}_{4}$ ". Treated roots were then fixed with Carnoy's fixative for $24 \mathrm{~h}$. before preservation in $70 \%$ alcohol. Slides of squashed root tips were prepared for cytogenetic investigation [25]. Effects of examined chemical treatments on different mitotic phases in relative to the untreated roots (controls) were observed under Olympus light microscope. To determine the effect on mitotic index, 3000 cells from three replicates were scored in control group and in each treated sample. Images were captured with Celestron Digital Imager HD.

Mitotic indexes and Percentages of cells showing chromosomal abnormalities and types of abnormality were recorded at the appropriate mitotic stages.

Mitotic index is calculated by this formula:Mitotic index $=\frac{\text { Number of dividing cells }}{\text { Total number of cells observed }} \times 100$.

\section{Results}

Transmission electronic microscope (TEM) investigations is counted and documented as a powerful tool to study and observe the material features and morphology, such as the size, thickness structure, distribution and boundaries of its particles. Here in this work TEM is used to emphasize the success of preparation of nanoparticles from normal sized materials, also to show any presence of aggregates and/or agglomerates of nano-particles in suspension.

\section{On the level of PVP/zinc nanoparticles (Zn NPs) prepared without gamma irradiation}

As illustrated in Fig. 1a, Zinc/PVP before irradiation confirms that the particles are almost hexagonal with slight variation in thickness. In addition, the images indicate the presence of zinc nanoparticles in polymer capping.

Figure $1 \mathrm{~b}$ clarifies the dimensions range of zinc nanoparticles. Dimensions were within the range between 11.6 to $98.2 \mathrm{~nm}$. Moreover, the mean size was calculated from the typical of 9 particles which equaled $41 \mathrm{~nm}$.

This result confirms that PVP can be successfully used for the preparation of zinc nanoparticles as a capping material.

\section{On the level of PVP/P nanoparticles prepared without gamma irradiation}

The TEM image (Fig. 2) illustrates the distribution of cubic and pyramidal phosphorous nanoparticle prepared without Gamma irradiation and emphasize the successful usage of PVP as coating material which capped P by dendritic branched functionalized PVP network.

Figure 3, TEM image that demonstrates the size distribution values of phosphorus nanoparticles were found to be in the range over (37.4-52.7) $\mathrm{nm}$. 

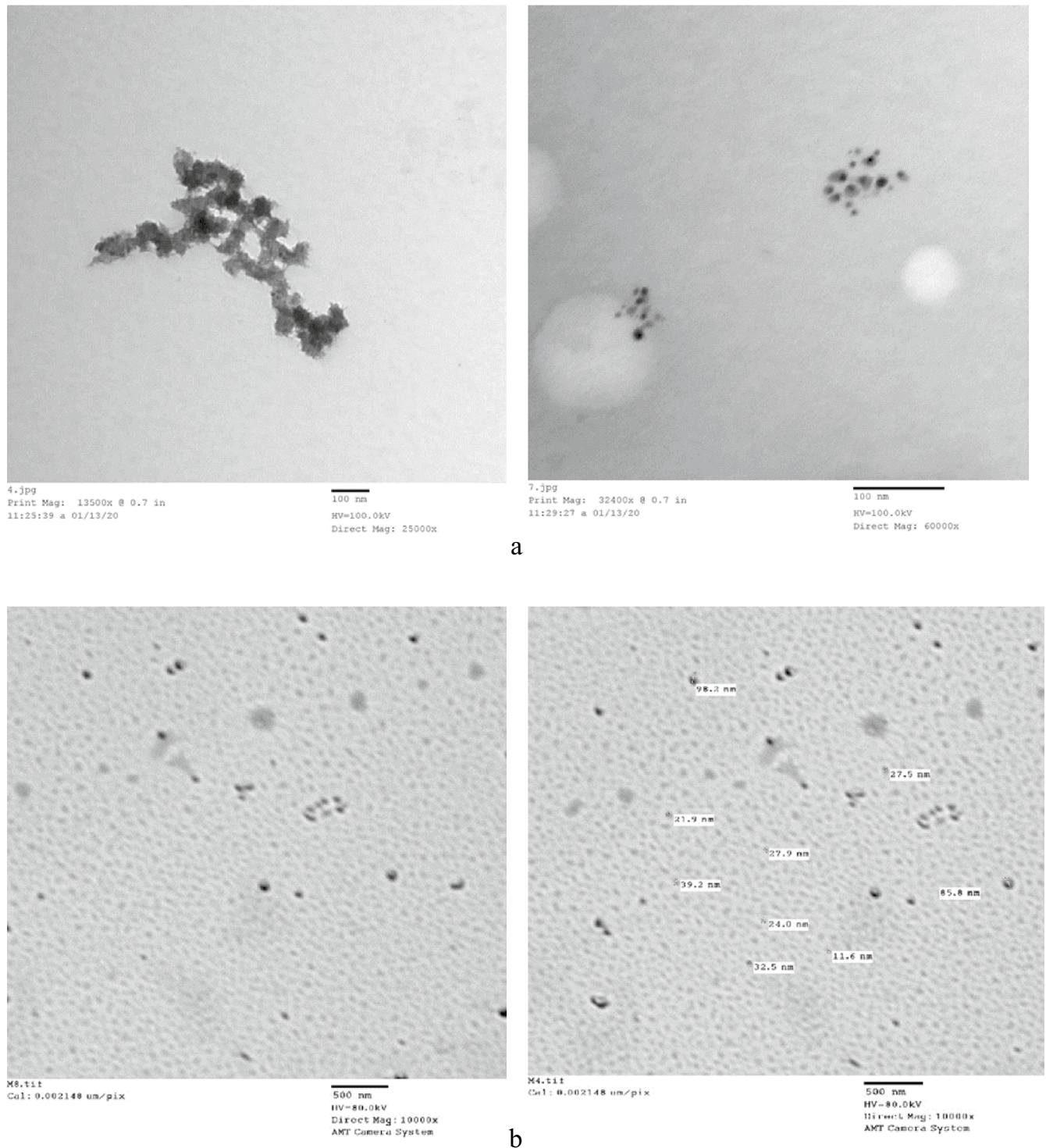

Fig. 1 a, b TEM images for PVP/zinc nanoparticles prepared without gamma irradiation (a) and the corresponding size of zinc nanoparticles which prepared without gamma radiation $(\mathbf{b})$

\section{On the level of $\mathrm{Zn} / \mathrm{P}$ nanoparticles prepared without gamma irradiation}

The obtained TEM captured images illustrate the nanostructure of the prepared $\mathrm{Zn}-\mathrm{P}$ mixture (Fig. 4), it is obvious, that Zn-P NP mixture appeared in different shapes including pyramidal, quasi-spherical and rhombus with an average size of $38 \mathrm{~nm}$ in diameter.

TEM images as shown in Fig. 4 also confirmed the stabilization of the nanoparticles by capping effect of the dendritic branched functionalized PVP network.

Figure $5 \mathrm{a}-\mathrm{f}$ confirms the crystalline structure of zinc nanoparticles embedded in the amorphous network of
PVP prepared via gamma irradiation and illustrates the size of selected one zinc nanoparticle in $\mathrm{PVP} / \mathrm{Zn}$ is about $12.83 \mathrm{~nm}$ (a), the cubic or rhombus shaped zinc nanoparticles (b), determine the observed size values ranged from 7.5 to $12.8 \mathrm{~nm}$ with the average size $10 \mathrm{~nm}(\mathrm{c}, \mathrm{d})$, the appearance of lattice fringes with interplanar spacing of $0.38 \mathrm{~nm}$. (e) and shows the selected area electron diffraction (SAED) pattern that clarified (f).

The captured images with the HRTEM in Fig. 6a-h, illustrate the morphology and crystallinity of the phosphorous nanoparticles stabilized PVP prepared via gamma irradiation. The morphology of phosphorous 

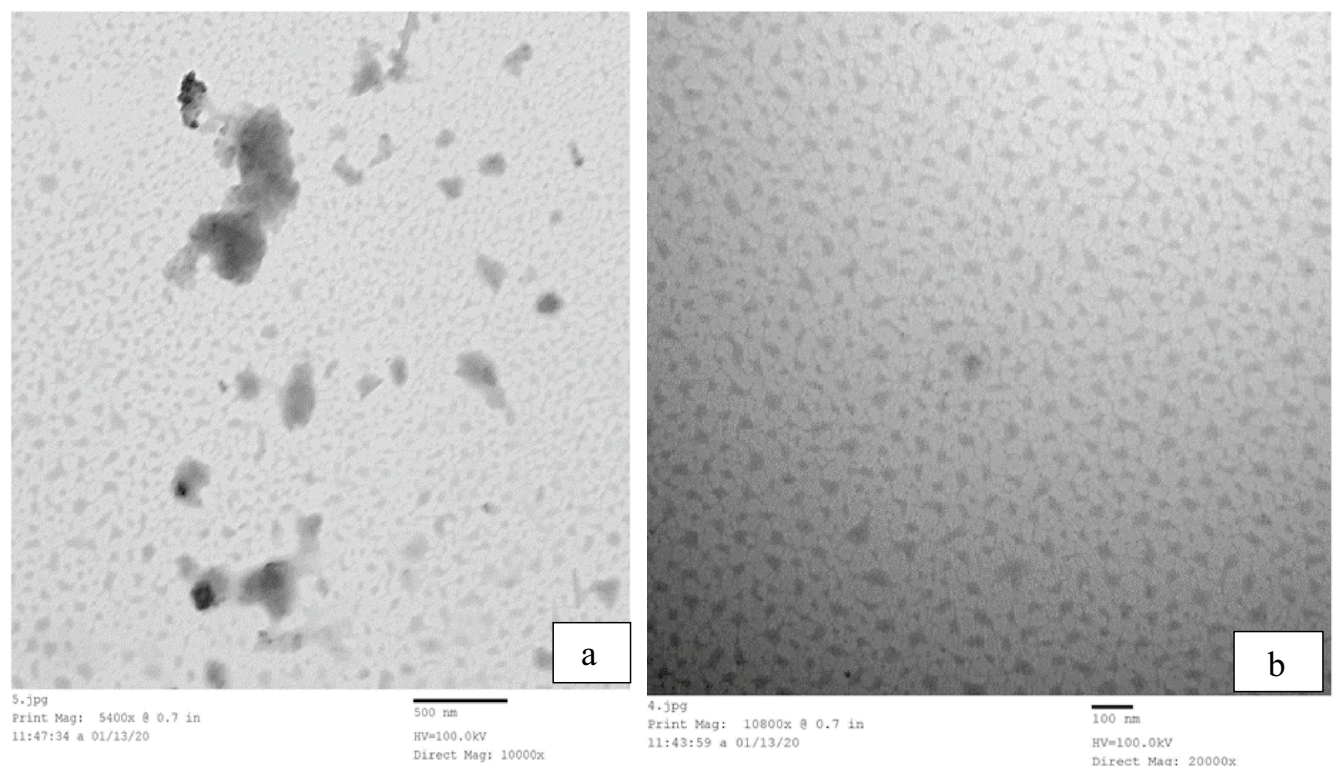

Fig. 2 a, b TEM images of PVP/P nanoparticles which prepared without gamma irradiation (b) and dendritic branched functionalized PVP matrix network
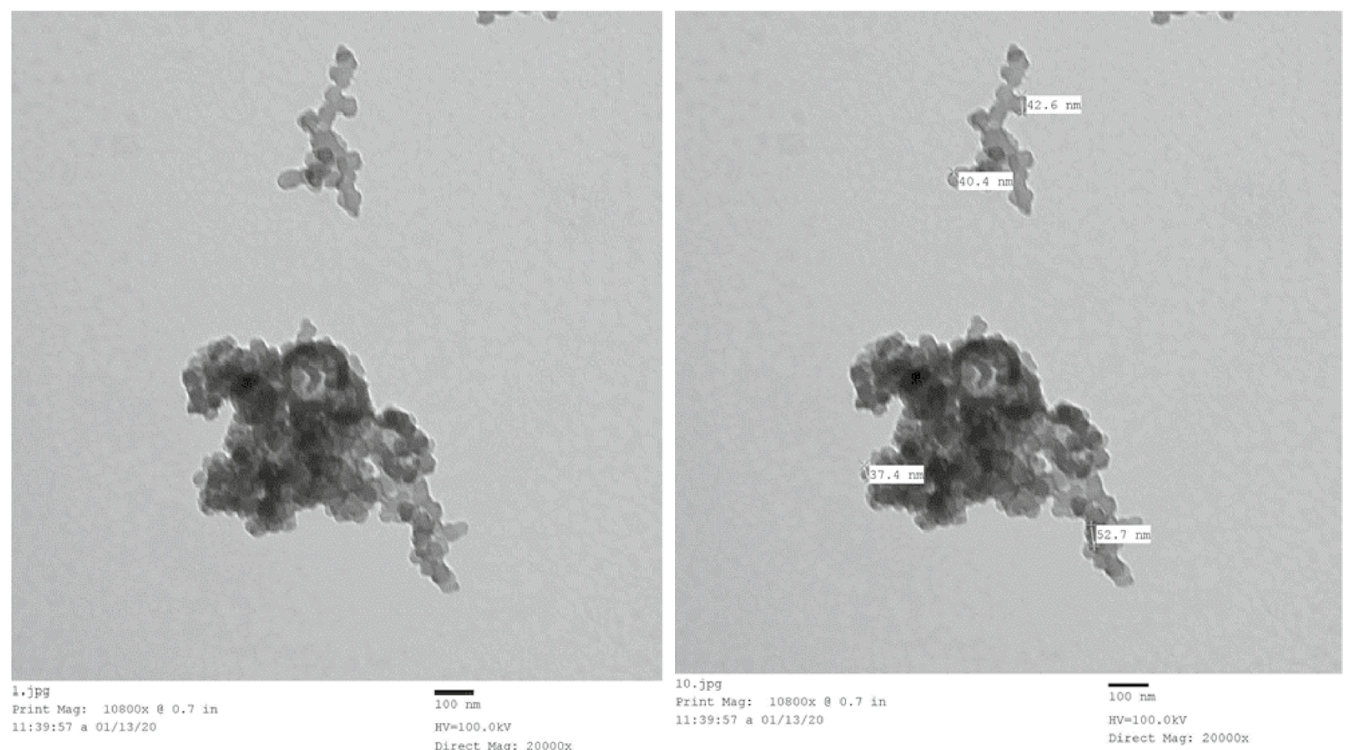

Fig. 3 TEM image illustrates the size distribution values of phosphorous nanoparticles prepared without gamma irradiation

nanoparticles was revealed in (a, c, and d), which illustrate that the nanoparticles are cubic and quasi-spheroidal in shape. As shown in Fig. 6d, f, it can be noticed that the average particle size is $17.6 \mathrm{~nm}$. Figure $6 \mathrm{~h}$ manifests the selective area electron diffraction (SAED) pattern of the highlighted area, which further signifies the occurrence of perfectly crystalline phosphorous nanoparticles. Clear lattice fringes were observed with interplanar spacing of $0.43 \mathrm{~nm}$.

The particle size and shape of the nano-sized $\mathrm{Zn} / \mathrm{P}$ were examined by HRTEM, as illustrated in Fig. $7 \mathrm{a}-\mathrm{f}$. The nanosized $\mathrm{Zn} / \mathrm{P}$ morphological shape are trigonal 

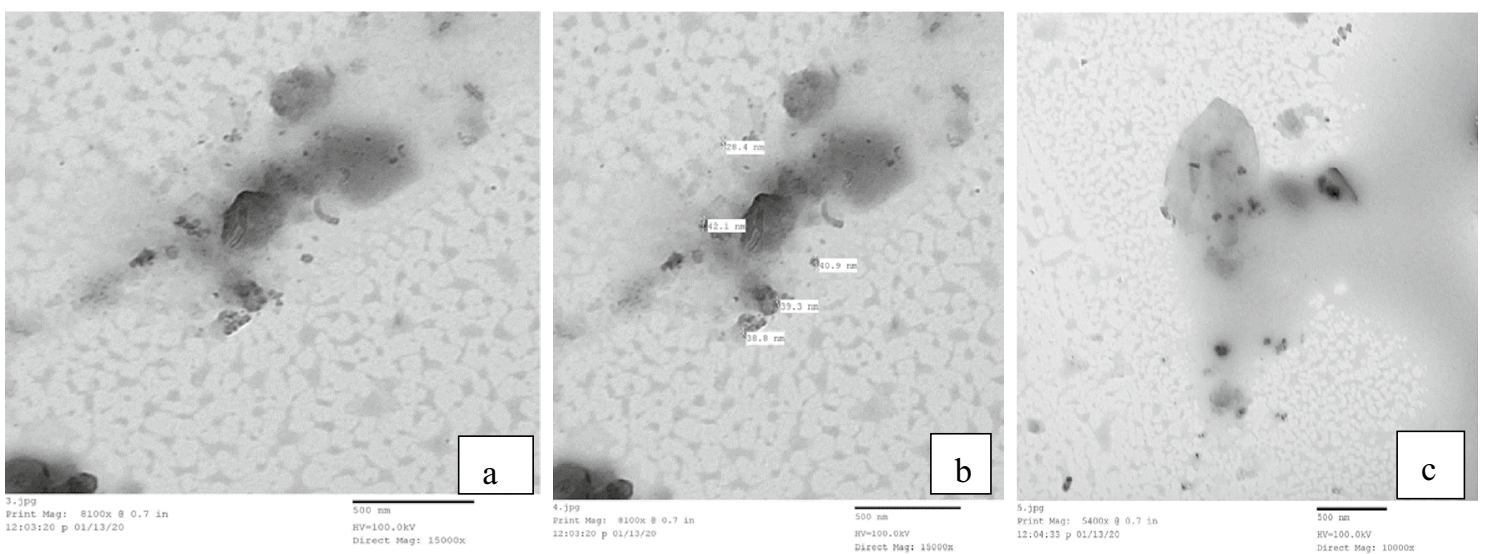

Fig. 4 a TEM images of Zn-P nanoparticles distribution in the dendritic branched functionalized PVP matrix network, $\mathbf{b}$ size distribution values of $\mathrm{Zn}-\mathrm{P}$ nanoparticles, $\mathbf{c}$ different shapes of Zn-P nanoparticles (pyramidal, quasi-spherical and rhombus)
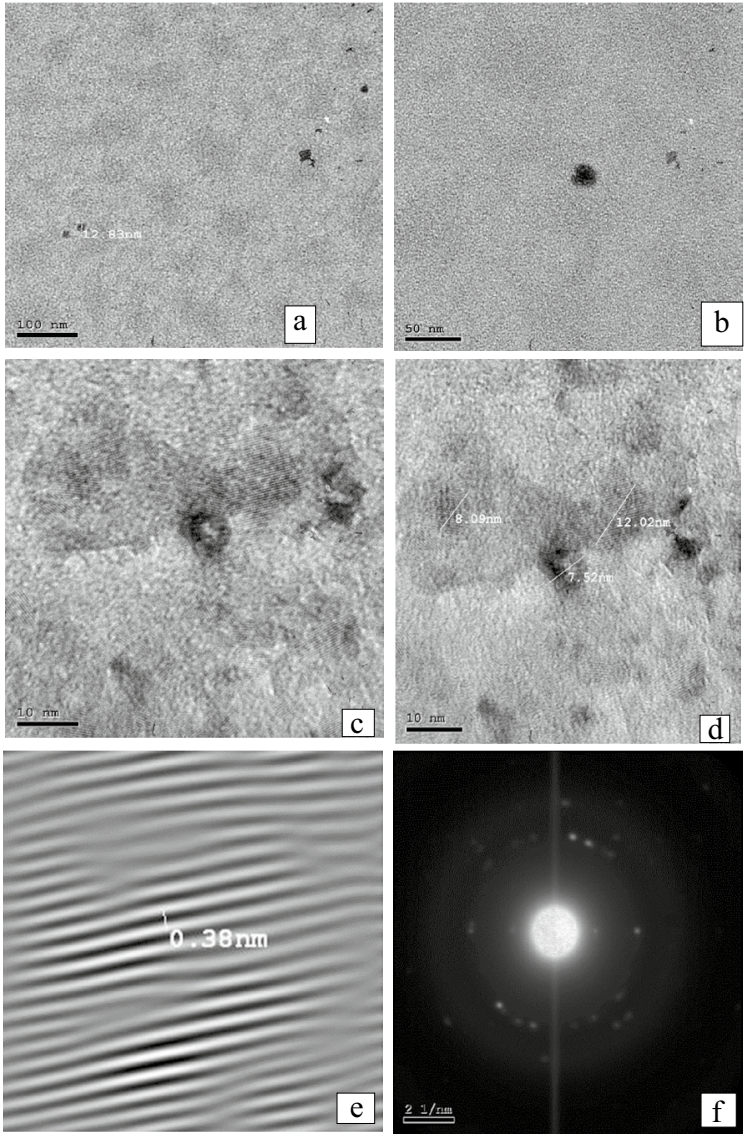

Fig. 5 a-f Representative HRTEM photographs show: the size of selected one zinc nanoparticle in PVP/Zn (a), cubic and rhombus shapes of zinc nanoparticles (b), the zinc NPs lattice fringes with corresponding size distribution of selected three particles $(\mathbf{c}, \mathbf{d})$, zinc nanoparticles lattice fringes with corresponding $d$-spacing value of $0.38 \mathrm{~nm}(\mathbf{e})$, and SAED pattern for zinc nanoparticles (f) bipyramid and trapezoid in shape $(\mathrm{a}-\mathrm{c})$. The size of the $\mathrm{Zn} / \mathrm{P}$ nanoparticles ranged between $(9-14.5 \mathrm{~nm})$ with average particle size $10.45 \mathrm{~nm}$ (d). The layered crystal structure of $\mathrm{Zn} / \mathrm{P}$ nanoparticles stabilized PVP is observed from the HRTEM images (Fig. 7c-f), which also confirms the crystalline nature of $\mathrm{Zn} / \mathrm{P}$. Figure $\mathrm{f}$ depicts the SEAD pattern of $\mathrm{Zn} / \mathrm{P}$ nanoparticles. It shows the well-organized concentric circular rings. This type of pattern mainly arises from the reflection of regularly arranged atoms. It authentically confirms the crystalline nature of $\mathrm{Zn} / \mathrm{P}$ nanoparticles. Figure $7 \mathrm{e}$ represents the appearance of lattice fringes with interplanar spacing of $0.49 \mathrm{~nm}$.

\section{On the level of UV-visible spectroscopy characterization}

Figure 8 illustrates the UV-visible absorption spectra for ZnOPVP. The characteristic peaks are at 290 and $430 \mathrm{~nm}$ due to the $\pi-\pi^{*}$ and $n-\pi^{*}$ transition, respectively. The presence of these peaks is confirming the successful formation of $\mathrm{ZnO}$ nanocomposite in agree with [26].

Figure 9 illustrates the UV-visible absorption spectrum of $\mathrm{PVP} /$ phosphorous nanoparticles and Fig. 10 illustrates the PVP/Zn-P nanoparticles both display a clear absorption band centered at $292 \mathrm{~nm}$, attributed to $\pi-\pi^{*}$ transitions of $\mathrm{N}=\mathrm{P}, \mathrm{C}=\mathrm{C}$, or $\mathrm{C}=\mathrm{N}$ groups in agree with [27] who reported that the UV-absorption band for phosphorus co-doped carbon dots was observed at $288 \mathrm{~nm}$.

Figure 11 is a constructed figure that illustrates the combined UV-visible absorbance spectrum of the three nanoparticles (A) Zn/PVP, (B) P/PVP (C) P-ZN/PVP. This figure confirms that the UV-visible absorbance characteristics possess strong relationships with size and shape of nanoparticle, as the spectrum recorded after $\mathrm{Zn}-\mathrm{P} / \mathrm{PVP}$ is intermediated between the two spectra $\mathrm{Zn} /$ PVP and P/PVP thus came in agree with [11]. 

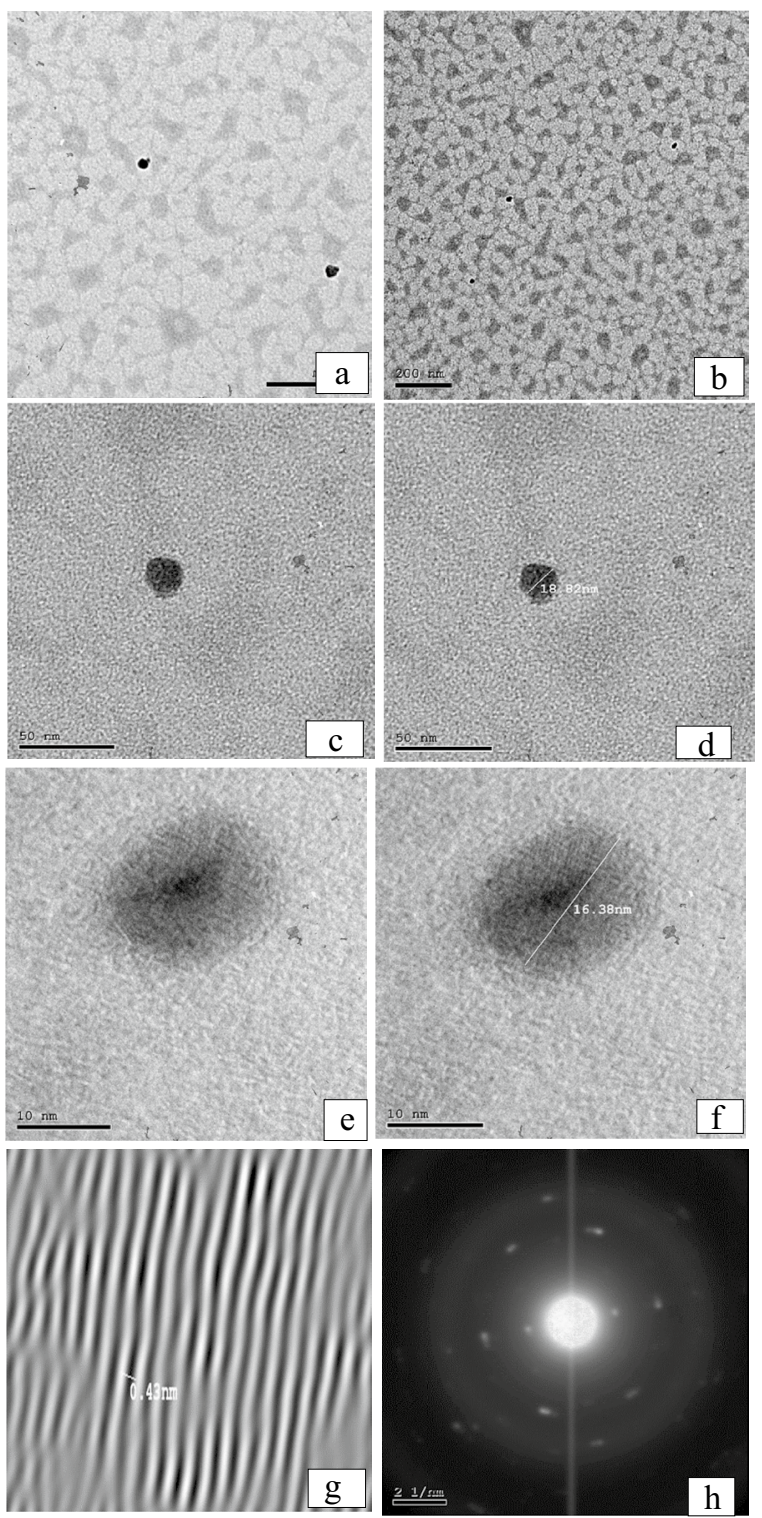

Fig. 6 a-h Representative HRTEM photographs show the phosphorous nanoparticles (a), the dendritic branched functionalized PVP matrix network after gamma irradiation (at $5 \mathrm{kGy}$ ) (b), the size value for two particles of phosphorous nanoparticles $(\mathbf{c}-\mathbf{f})$, the phosphorous nanoparticles lattice fringes with corresponding $\mathrm{d}$-spacing value of $0.43 \mathrm{~nm}(\mathbf{g})$ and SAED pattern for phosphorous nanoparticles $(\mathbf{h})$

\section{On the level of FT-IR characterization}

FTIR will be employed to show the influence of a nanofiller on the properties of nanocomposite films through changes in the band intensity of FTIR spectra.

The presence of diverse chemical functional groups in PVP embedded zinc nanoparticles is indicated by FTIR spectra, as shown in Fig. 12. The broad absorption band located between (3077-3662) $\mathrm{cm}^{-1}$, which centered at $3386 \mathrm{~cm}^{-1}$ is result of $\mathrm{O}-\mathrm{H}$ stretching
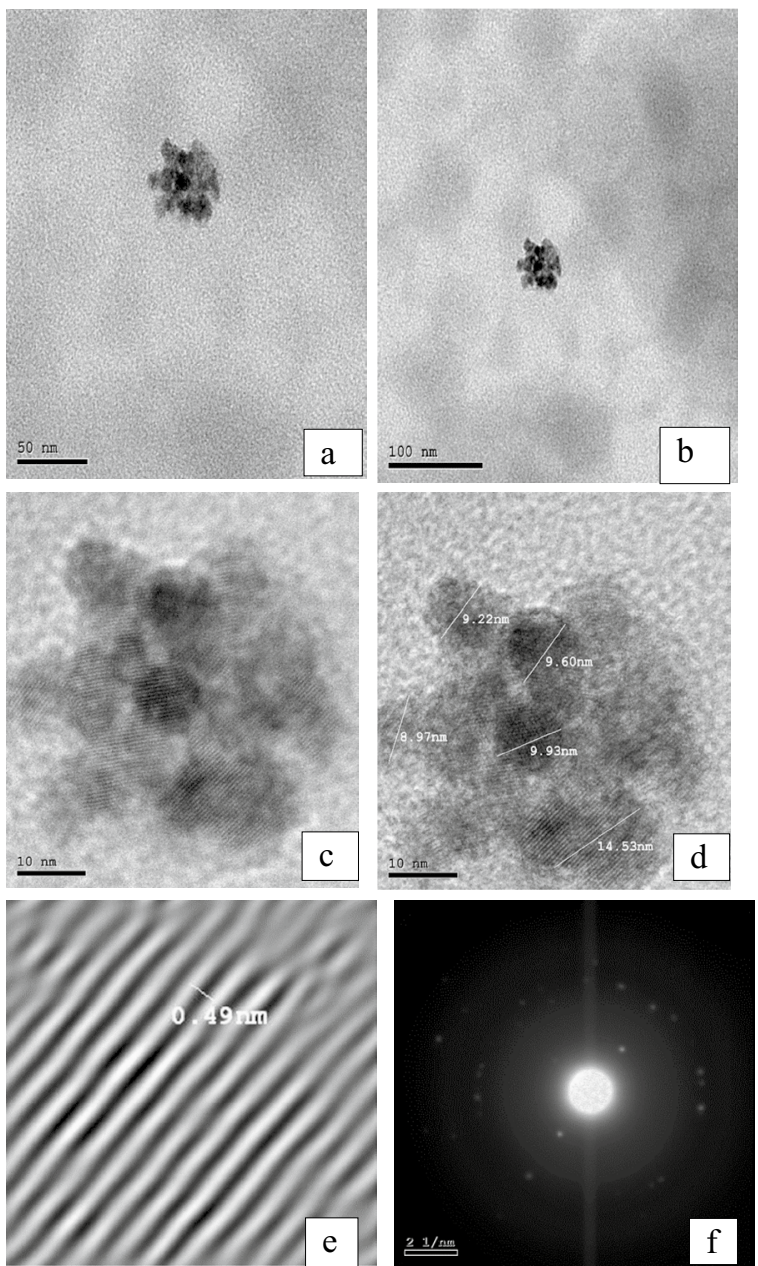

Fig. 7 a-f HRTEM images of $Z n / P$ nanoparticles $(\mathbf{a}, \mathbf{b})$, the corresponding morphology and size for five particles of $\mathrm{Zn} / \mathrm{P}$ nanoparticles (c, d), The lattice fringes with corresponding $d$-spacing value of $0.49 \mathrm{~nm}$ of $\mathrm{Zn} / \mathrm{P}$ nanoparticles (e) and SAED pattern of $\mathrm{Zn} / \mathrm{P}$ nanoparticles (f)

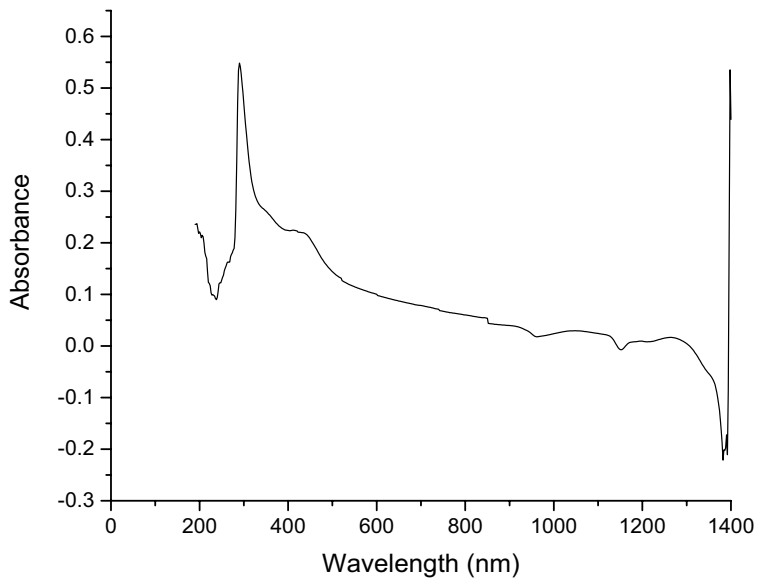

Fig. 8 UV-visible absorbance spectra of ZnO/PVP nanoparticles 


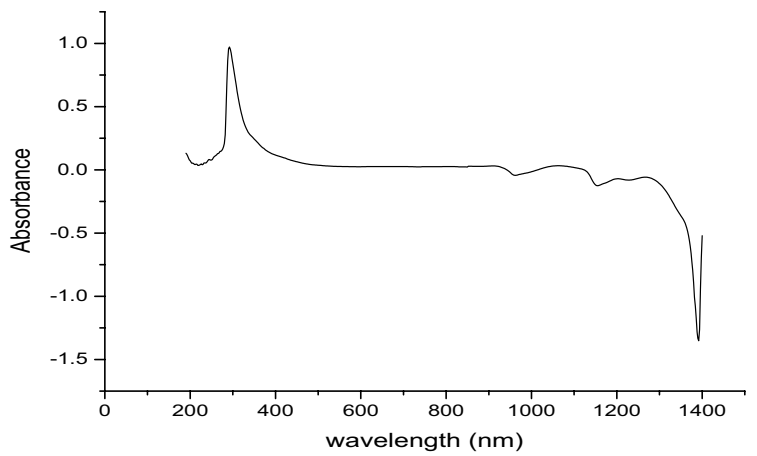

Fig. 9 UV-visible absorbance spectra of P/PVP nanoparticles

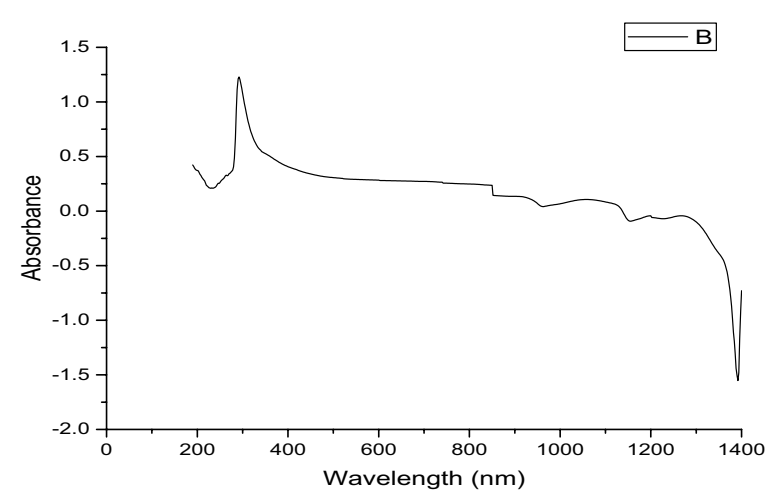

Fig. 10 UV-visible absorption spectrum of Zn-P/PVP nanoparticles vibrations of adsorbed water at the surface of particles. A double strong peak at $1660 \mathrm{~cm}^{-1}$ and $1634 \mathrm{~cm}^{-1}$ is assigned to the stretching vibration of the $\mathrm{C}=\mathrm{O}$ and $\mathrm{C}=\mathrm{C}$ stretching, respectively. Another important peaks at $1294 \mathrm{~cm}^{-1}, 1426 \mathrm{~cm}^{-1}$, and $1411 \mathrm{~cm}^{-1}$ are assigned to the $\mathrm{C}-\mathrm{N}$ stretching vibrations and the attachment of $\mathrm{CH}_{2}$ groups in the pyrrole ring of PVP. The absorption peak at $1380 \mathrm{~cm}^{-1}$ due to the $\mathrm{C}-\mathrm{H}$ bond in PVP. This came in agree with Selvi et al. [28] how reported that nano-sized $\mathrm{ZnO}$ has FTIR peak around $500 \mathrm{~cm}^{-1}$ which related to $\mathrm{M}-\mathrm{O}$ (metal oxide) stretching. The presence of $\mathrm{M}-\mathrm{O}$ stretching authentically proves the formation of $\mathrm{ZnO}$ NPs. Hence, on adding zinc nanoparticles (zinc oxide) to (PVP/glycerol/phosphoric acid), there is a displacement of 1112 to $11,109 \mathrm{~cm}^{-1}, 1182$ to $1171 \mathrm{~cm}^{-1}$, 1423 to $1418 \mathrm{~cm}^{-1}$, and 1642 to $1632 \mathrm{~cm}^{-1}$. It is noted that the equivalent peaks were shifted to the lower wave number and their intensities were changed after the addition of zinc nanoparticles. This authentically proves the actual physical interaction between nano-sized $\mathrm{ZnO}$ and the PVP matrix. The interaction of $\mathrm{ZnO}$ with the polymer matrix is also confirmed by the presence of the $\mathrm{M}-\mathrm{O}$ stretching peak around $500 \mathrm{~cm}^{-1}$. The charge transfer complex can be formed by the interaction of the $\mathrm{C}=\mathrm{O}$ or $\mathrm{C}-\mathrm{O}-\mathrm{C}$ group of PVP with $\mathrm{ZnO}$ NPs through chelation.

The chemical interaction between PVP, Glycerol, and Phosphoric acid after gamma irradiation was investigated and proven by FT-IR. Figure 13 shows FT-IR of PVP/

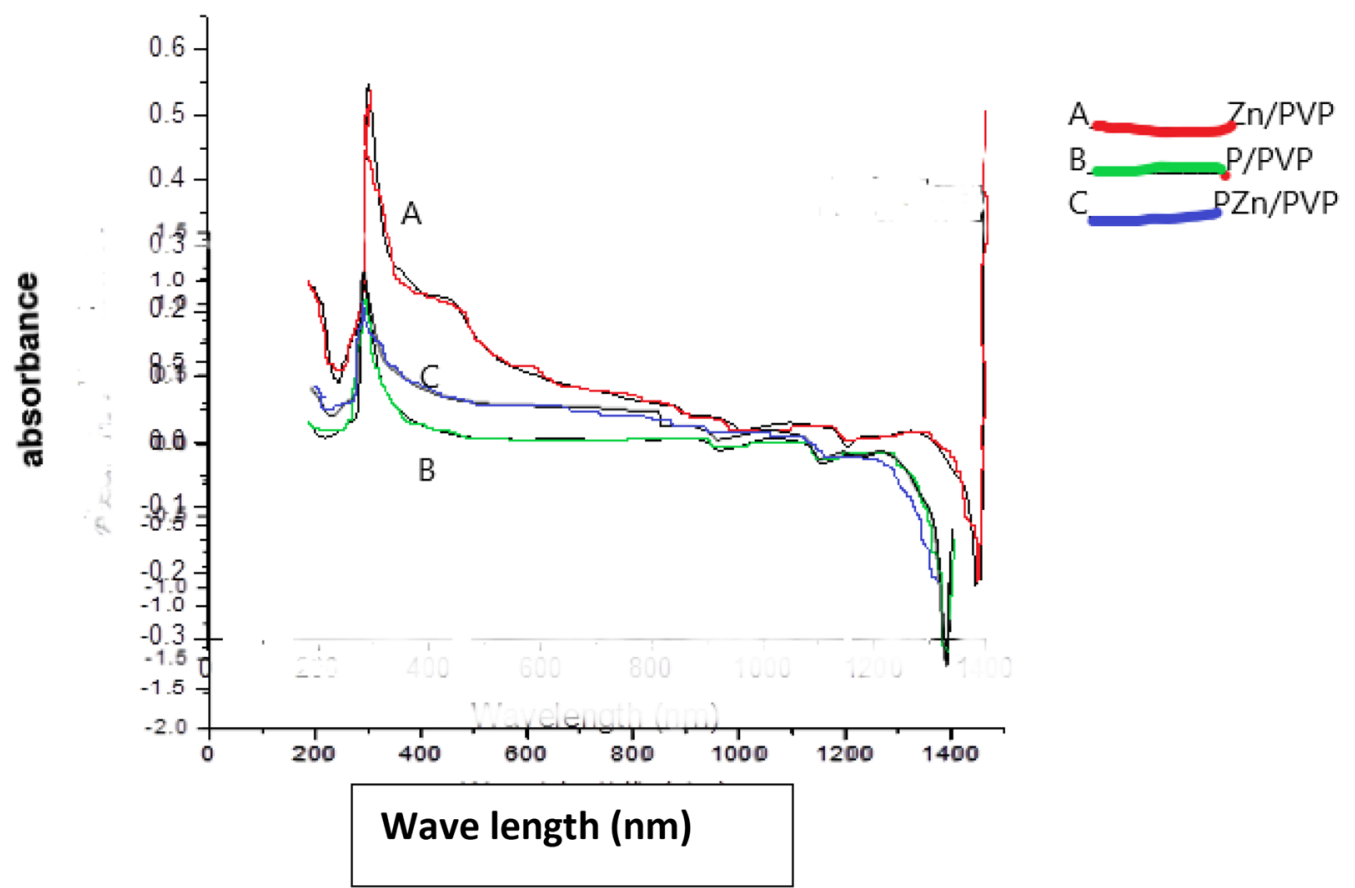

Fig. 11 Constructed UV-visible absorbance spectra of $\mathbf{A}$ ZnO/PVP, B P/PVP, C P-ZN/PVP nanoparticles 


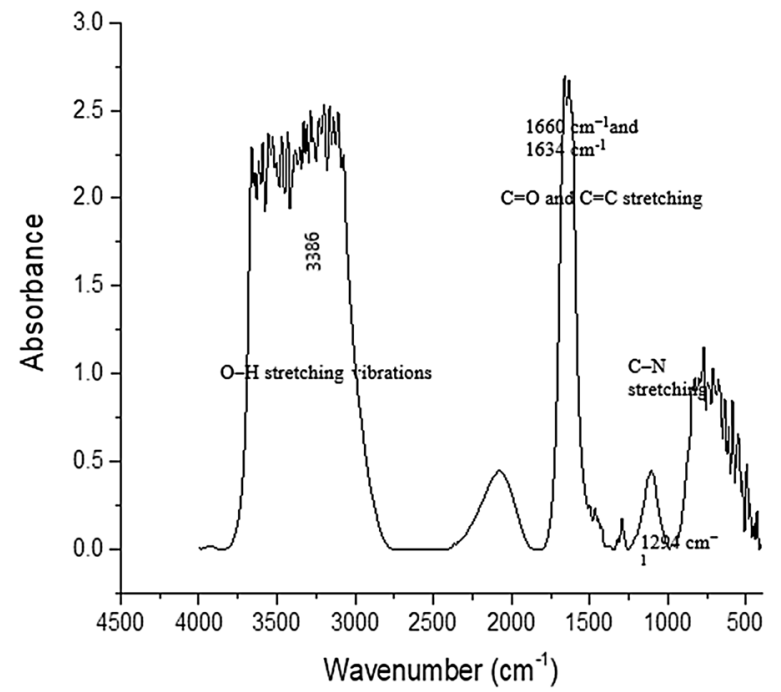

Fig. 12 FTIR spectrum of PVP/Zn nanoparticles. The main IR vibrational assignments are denoted inside the figure

glycerol/phosphoric acid at irradiation dose $5 \mathrm{kGy}$. The strong broad beak present between 3137 and $3573 \mathrm{~cm}^{-1}$ is assigned to $(\mathrm{OH})$ stretching. The band appropriate to $\mathrm{CH}_{2}$ asymmetric stretching vibration appears at about 2891 and $2951 \mathrm{~cm}^{-1}$.

The band associated with the $\mathrm{C}-\mathrm{O}$ and $\mathrm{P}-\mathrm{O}-\mathrm{P}$ stretching vibrations, at about $1001 \mathrm{~cm}^{-1}$. The broad band between 2200 and $2400 \mathrm{~cm}^{-1}$ which includes the doubly degenerate stretching mode for $C \Xi C$ and $C \Xi N$. There is another discussion, [29] suggested that, the peaks at 2346 and $2381 \mathrm{~cm}-1$ assigned to $\mathrm{C}=\mathrm{O}$ bond. In addition, the band around $2327 \mathrm{~cm}^{-1}$ was found to be attributed to $\mathrm{P}-$ $\mathrm{OH}[30]$.

In (Fig. 13), the peak at $1182 \mathrm{~cm}^{-1}$ is corresponding to $\mathrm{C}-\mathrm{O}-\mathrm{C}$ asymmetric stretching, and the peak at $1112 \mathrm{~cm}^{-1}$ is attributed to the $\mathrm{C}-\mathrm{O}$ stretching vibration. In another proposed view, the peaks at 1112 and $1001 \mathrm{~cm}^{-1}$ may be assigned to $\mathrm{C}-\mathrm{N}$ bonds [31].

The bands observed at $1423 \mathrm{~cm}^{-1}$ and $1464 \mathrm{~cm}^{-1}$ are matched to $\mathrm{CH}$ bending of $\mathrm{CH}_{2}$ and/or $\mathrm{OH}$ bending in agrees with [32], who declared that the band at $1423 \mathrm{~cm}^{-1}$ is corresponding to the $\mathrm{CH}$ deformation modes from the $\mathrm{CH}_{2}$ group. The $\mathrm{C}-\mathrm{H}$ bending modes (out of plane) were observed in the range (674-926 cm-1). Moreover, it has been noticed that the band appeared at $495 \mathrm{~cm}^{-1}$ is due to $\mathrm{C}-\mathrm{C}-\mathrm{N}$ deformation made [33].

In Fig. 14, the FT-IR spectrum of PVP containing $\mathrm{Zn}-\mathrm{P}$ nanoparticles shows the same characteristic peaks of the sample contains (PVP/glycerol/phosphoric acid) (Fig. 13). It is obvious that, on adding zinc nanoparticles (zinc oxide) to (PVP/glycerol/phosphoric acid), there is a noticed displacement of 1112 to $11,109 \mathrm{~cm}^{-1}, 1182$ to $1171 \mathrm{~cm}^{-1}, 1423$ to $1418 \mathrm{~cm}^{-1}$, and 1642 to $1632 \mathrm{~cm}^{-1}$. In other word, the equivalent peaks were shifted to the lower wave number and their intensities were changed after the addition of zinc nanoparticles.

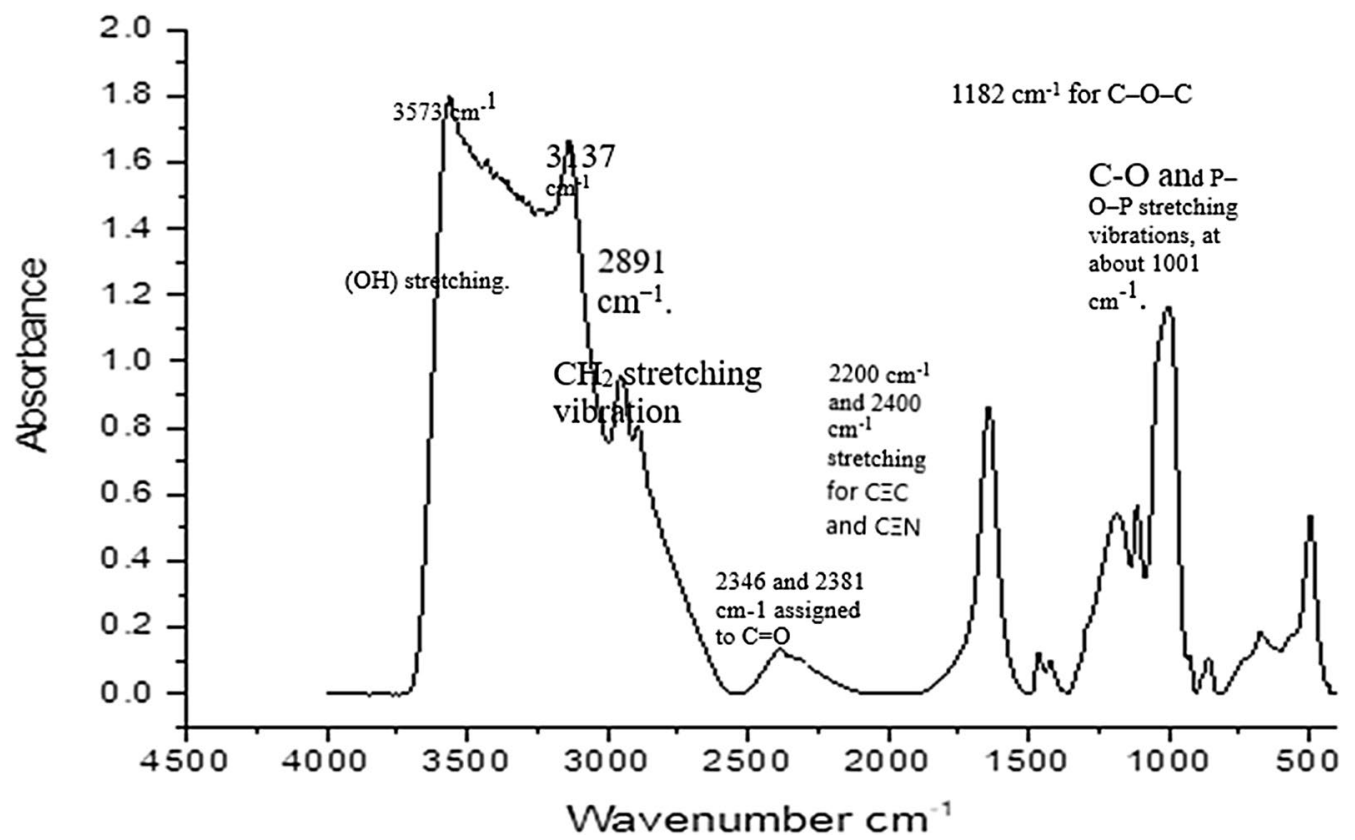

Fig. $13 \mathrm{FTIR}$ spectrum of PVP/P nanoparticles. The main IR vibrational assignments are denoted inside the Figure 


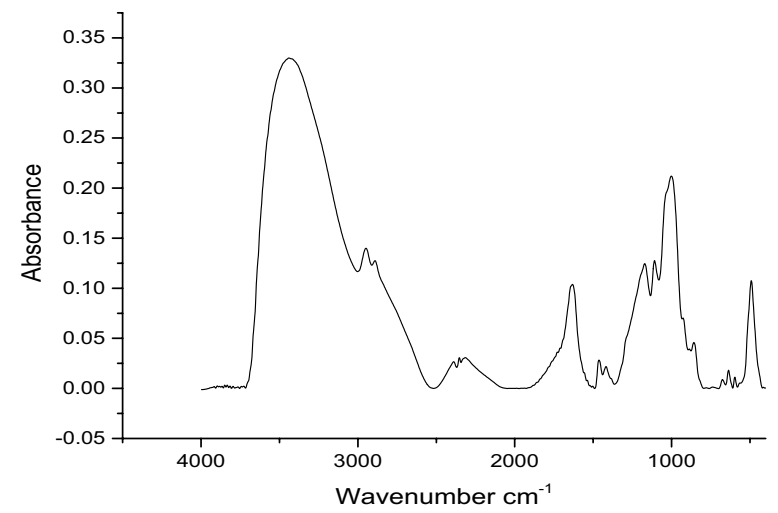

Fig. 14 FTIR spectrum of PVP/Zn-P nanoparticles at irradiation dose 5 kGy

\section{On the cytogenetic studies level}

It well known that, mitosis is that system enables the organisms to grow, repair the damaged cells, and proliferates the health and viability. The mitosis can be evaluated via parameters, such as mitotic index, phase index and percentages of abnormal mitosis at each phase.

Mitotic index means the percentage of cells to go through division, any alteration in this index is considered as a parameter for the cytotoxicity [34]. As illustrated in Table 1; the collected data revealed that each of the three nano-preparations increased the mitotic index relative to control (7.1\%). The highest mitotic index $(10.8 \%)$ was recorded after direct treatment with $0.5 \%$ of $\mathrm{Zn}$ NPs followed by the mitotic index (10.3\%) recorded after treatment with $2 \%$ of P NPs.

Among the three preparations, Zn NPs showed a concentration dependent reduction in mitotic index; this came in agree with [21] when tested the ZnO NPs in high concentration on A. cepa root tip meristems. On the other hand, the P NPs showed a concentration dependent increase in the mitotic index, while the treatment with the Zn/P NPs which is a mixture between the two other preparations showed a moderate but fluctuated and not concentration dependent increase in mitotic indexes (Table 1).

Regarding the effect of the tested preparations on the mitotic phase index as an indicator for the direct effect on the cell cycle, the obtained data revealed that treatment with the two higher examined concentrations 1 and $2 \%$ of Zn NPs and with P NPs showed a concentration dependent decrease in the prophase frequencies ranged from (35.48 to $31.06 \%$ ) on responses to other two phases same was previously recorded by [20] when tested the CuNPs on Alium cepa roots.

On the level of mixing the Zn-P/PVP (Zn/P NPs) nanoparticles, our obtained data on phase duration showed an increase in the prophase frequency (45.06 and $41.66 \%)$, respectively, relative to control (38.5\%) which may be explained by the enhancement effect of the nanomixture (Table 1).

Regarding the percentage of abnormal mitosis as an indicator for the mutagenicity of the tested materials; the obtained data showed a significant increase in the percentage of chromosomes abnormality relative to control, these results came on agree with [35] when tested the AgNPs on the roots of Allium cepa and reported that, it exhibited increase in the frequency of chromosomal aberrations. Here, we have to point to the concentration dependent decrease in the chromosomes' abnormality after treatment with Zn NPs and concentration dependent increase in the abnormality after treatment with $\mathrm{Zn} / \mathrm{P}$ NPs, while treatment with P NPs induced a concentration independent (fluctuated) abnormal mitosis. The highest abnormal mitosis $(26.81 \%)$ was recorded after treatment

Table 1 Mitotic and phase indexes and percentages of abnormal mitosis and abnormality in each mitotic phase in Vicia faba root-tip meristems, after $3 \mathrm{~h}$ treatment with three prepared nanoparticles stabilized PVP which prepared via gamma irradiation 5KGy

\begin{tabular}{|c|c|c|c|c|c|c|c|c|c|c|c|}
\hline \multirow[t]{2}{*}{ Treatment } & \multirow[t]{2}{*}{ Concentration } & \multirow[t]{2}{*}{ Tot. cell } & \multirow[t]{2}{*}{ Dividing } & \multicolumn{2}{|c|}{ Prophase } & \multicolumn{2}{|c|}{ Metaphase } & \multicolumn{2}{|c|}{ Ana-telophase } & \multirow[t]{2}{*}{$\%$ ab } & \multirow[t]{2}{*}{ MI } \\
\hline & & & & Index & $\%$ ab & Index & $\% a b$ & Index & $\% a b$ & & \\
\hline \multirow[t]{3}{*}{$\mathrm{PVP}+\mathrm{ZnO}$} & $0.50 \%$ & 3000 & 324 & 45.06 & 6.8 & 10.49 & 50.0 & 44.44 & 18.05 & 16.35 & 10.8 \\
\hline & $1.00 \%$ & 3000 & 279 & 35.48 & 4.04 & 26.88 & 29.57 & 37.63 & 16.19 & 15.05 & 9.3 \\
\hline & $2.00 \%$ & 3000 & 228 & 31.14 & 2.82 & 19.74 & 33.33 & 49.12 & 10.71 & 12.72 & 7.6 \\
\hline \multirow[t]{3}{*}{$\mathrm{PVP}+$ glycerol $+\mathrm{H}_{3} \mathrm{PO}_{4}$} & $0.50 \%$ & 3000 & 276 & 41.66 & 6.96 & 25 & 55.07 & 33.33 & 30.43 & 26.81 & 9.2 \\
\hline & $1.00 \%$ & 3000 & 285 & 31.5 & 7.77 & 20.00 & 42.10 & 48.42 & 15.94 & 18.59 & 9.5 \\
\hline & $2.00 \%$ & 3000 & 309 & 31.06 & 8.33 & 29.44 & 49.45 & 39.48 & 13.93 & 22.65 & 10.3 \\
\hline \multirow[t]{3}{*}{$\mathrm{PVP}+$ Glycerol $+\mathrm{ZnO}+\mathrm{H}_{3} \mathrm{PO}_{4}$} & $0.50 \%$ & 3000 & 261 & 26.82 & 7.14 & 22.22 & 34.48 & 50.95 & 19.54 & 19.54 & 8.7 \\
\hline & $1.00 \%$ & 3000 & 275 & 35.27 & 6.97 & 22.54 & 46.77 & 46.18 & 15.75 & 20.00 & 9.2 \\
\hline & $2.00 \%$ & 3000 & 267 & 37.45 & 4.00 & 19.85 & 52.83 & 42.69 & 21.93 & 21.35 & 8.9 \\
\hline Control & & 3000 & 213 & 38.50 & 0 & 18.78 & 12.5 & 42.72 & 5.49 & 4.69 & 7.1 \\
\hline
\end{tabular}


with $0.5 \%$ P NPs followed by (22.65\%) after treatment with $2 \%$ of the same preparation. The lowest abnormal mitosis was $(12.72 \%)$ recorded after treatment with $2 \% \mathrm{Zn}$ NPs which is about three times the percentage (4.69\%) recorded in control (untreated plants) (Table 1).

It was previously recorded increase in chromosomes anomalies after treatment with $\mathrm{ZnO}$ NPs and attributed that increase to the massive adsorption into the root system and severe accumulation of ZnO NPs in both the cellular and the chromosomal modules [36].

As shown in Table 2, the three examined preparations Zn NPs, P NPs and Zn/P NPs induced chromosomes abnormalities, the observed chromosomal abnormalities were mainly of chromosomal kinetic abnormality type: disturbances (Plate 1: Figs. I, II, III, IV, V, VI, IX, XII), pro-metaphase (Plate 1: Fig. VII) and clumped chromosomes (Plate 1: Fig. III), chromosomes disturbance after treatment refers to the turbogenic effect of the tested materials arise from improper functioning of spindle apparatus to organize in a normal way [37], disturbance percentages ranged from $74.29 \%$ after treatment with $2 \%$ of P NPs to $54.05 \%$ after treatment with $0.5 \%$ of same treatment. The chromatin material liquefaction type came on second place: sticky chromosomes (Figs. II, VI, VIII, IX, X, XI) and sticky bridges. Chromatin stickiness refers to the chromo-toxic effects or polymorphism effect of the examined materials on nucleic acid of chromosomes by which it affects the proteinaceous matrix of chromatin material [37]. The induced percentages ranged from $33.78 \%$ (after treatment with $0.5 \%$ of $\mathrm{P}$ NPs) to $4.31 \%$ (after treatment with $0.5 \%$ of Zn/P NPs).

The chromosomal structural aberrations type: structural bridge (Plate 1: Fig. XI), breakage and fragments and ring chromosomes which refer to clastogenic oxidative effect of the tested NPs came in the last place in very few percentages, ranged from $0.0 \%$ (after $1 \% \mathrm{Zn} \mathrm{NPs}$ ) to $22.65 \%$ (after 1\% of P NPs).

Regarding the formation of micronuclei as true evidence on mutagenicity; resulted from partially loss of some of the genetic material [38]; data revealed that nano $\mathrm{Zn}$ fertilizer in higher used concentration $2 \%$ induced $3.45 \%$ of micronuclei which is lowered to $1.75 \%$ after $\mathrm{Zn} / \mathrm{P}$ mixtures which emphasize the enhancement and favorable effect of mixing the nano $\mathrm{P}$ to nano $\mathrm{Zn}$.

\section{Discussion}

As known; the most important transient products of water radiolysis, in the absence of oxygen, are hydroxyl radicals ${ }^{\circ} \mathrm{OH}$, hydrogen atoms $\mathrm{H}^{\circ}$, and hydrated electrons $\mathrm{e}_{\mathrm{aq}}{ }^{-}$[Eq. (1)]. When water radiolysis products react with polymers, such as PVP the hydrogen is abstracted from $\mathrm{C}$ atoms by ${ }^{\circ} \mathrm{OH}$ radicals [Eq. 2] by $\mathrm{H}^{*}$ atoms [Eq. 3]. As a result, a radical is formed at the carbon atom of the polymer, usually at a random position along the polymer chain, with concomitant formation of water or

Table 2 Percentage of the different types of abnormalities/scored number, occurring in the mitoses of Vicia faba root-tip meristems, after $3 \mathrm{~h}$ treatment with three prepared nanoparticles stabilized PVP which prepared via gamma irradiation 5KGy

\begin{tabular}{|c|c|c|c|c|c|c|c|c|c|c|c|c|c|}
\hline \multirow[t]{4}{*}{ Treatment } & \multicolumn{13}{|c|}{$\%$ of different types of abnormal mitoses/scored number } \\
\hline & \multicolumn{3}{|c|}{$\begin{array}{l}\text { Chromat. mater. } \\
\text { Liquefac. abn }\end{array}$} & \multicolumn{5}{|c|}{ Chromos. kinetic abnormality } & \multicolumn{5}{|c|}{ Chrom. structural aberr } \\
\hline & \multirow[t]{2}{*}{ Sti } & \multirow{2}{*}{$\begin{array}{l}\text { Sti. } \\
\text { br }\end{array}$} & \multirow[t]{2}{*}{ Sum } & \multicolumn{3}{|l|}{ Dist } & \multirow[t]{2}{*}{ Lag } & \multirow[t]{2}{*}{ Sum } & \multirow[t]{2}{*}{ Str.br } & \multirow[t]{2}{*}{ Frag. and break } & \multirow[t]{2}{*}{ Micro-nu } & \multirow[t]{2}{*}{ ring } & \multirow[t]{2}{*}{ Sum } \\
\hline & & & & Dist & Pro-m & Clump & & & & & & & \\
\hline \multicolumn{14}{|l|}{$\mathrm{PVP}+\mathrm{ZnO}$} \\
\hline $0.50 \%$ & 18.87 & 1.89 & 20.76 & 58.49 & 7.55 & 3.77 & 1.89 & 71.69 & 1.89 & 0.00 & 1.89 & 1.89 & 5.67 \\
\hline $1.00 \%$ & 33.33 & 0.00 & 33.33 & 50.00 & 9.52 & 7.14 & 0.00 & 66.66 & 0.00 & 0.00 & 0.00 & 0.00 & 0.00 \\
\hline $2.00 \%$ & 24.14 & 3.45 & 27.59 & 58.62 & 6.90 & 0.00 & 3.45 & 68.97 & 0.00 & 0.00 & 3.45 & 0.00 & 3.45 \\
\hline \multicolumn{14}{|l|}{$\begin{array}{l}\mathrm{Pvp}+\mathrm{Glyc}- \\
\mathrm{erol}+\mathrm{H}_{3} \mathrm{PO}_{4}\end{array}$} \\
\hline $0.50 \%$ & 32.43 & 1.35 & 33.78 & 35.14 & 14.86 & 2.70 & 1.35 & 54.05 & 2.70 & 8.11 & 0.00 & 1.35 & 12.16 \\
\hline $1.00 \%$ & 16.98 & 1.89 & 18.87 & 49.06 & 9.43 & 0.00 & 0.00 & 58.49 & 1.89 & 13.21 & 1.89 & 5.66 & 22.65 \\
\hline $2.00 \%$ & 22.86 & 1.43 & 24.29 & 65.71 & 1.43 & 2.86 & 4.29 & 74.29 & 0.00 & 1.43 & 0.00 & 0.00 & 1.43 \\
\hline \multicolumn{14}{|c|}{$\begin{array}{l}\mathrm{PVP}+\mathrm{Glyc}- \\
\mathrm{erol}+\mathrm{ZnO}+\mathrm{H}_{3} \mathrm{PO}_{4}\end{array}$} \\
\hline $0.50 \%$ & 2.35 & 1.96 & 4.31 & 50.98 & 0.00 & 3.92 & 0.00 & 54.9 & 19.61 & 0.00 & 0.00 & 0.00 & 19.61 \\
\hline $1.00 \%$ & 10.91 & 5.45 & 16.36 & 70.91 & 1.82 & 5.45 & 0.00 & 78.17 & 0.00 & 0.00 & 1.82 & 3.64 & 5.46 \\
\hline $2.00 \%$ & 22.81 & 5.26 & 28.07 & 50.88 & 12.28 & 1.75 & 3.51 & 67.54 & 1.75 & 0.00 & 1.75 & 0.00 & 3.5 \\
\hline Control & 30.00 & 0.00 & 30.00 & 40.00 & 30.00 & 0.00 & 0.00 & 70.00 & 0.00 & 0.00 & 0.00 & 0.00 & 0.00 \\
\hline
\end{tabular}




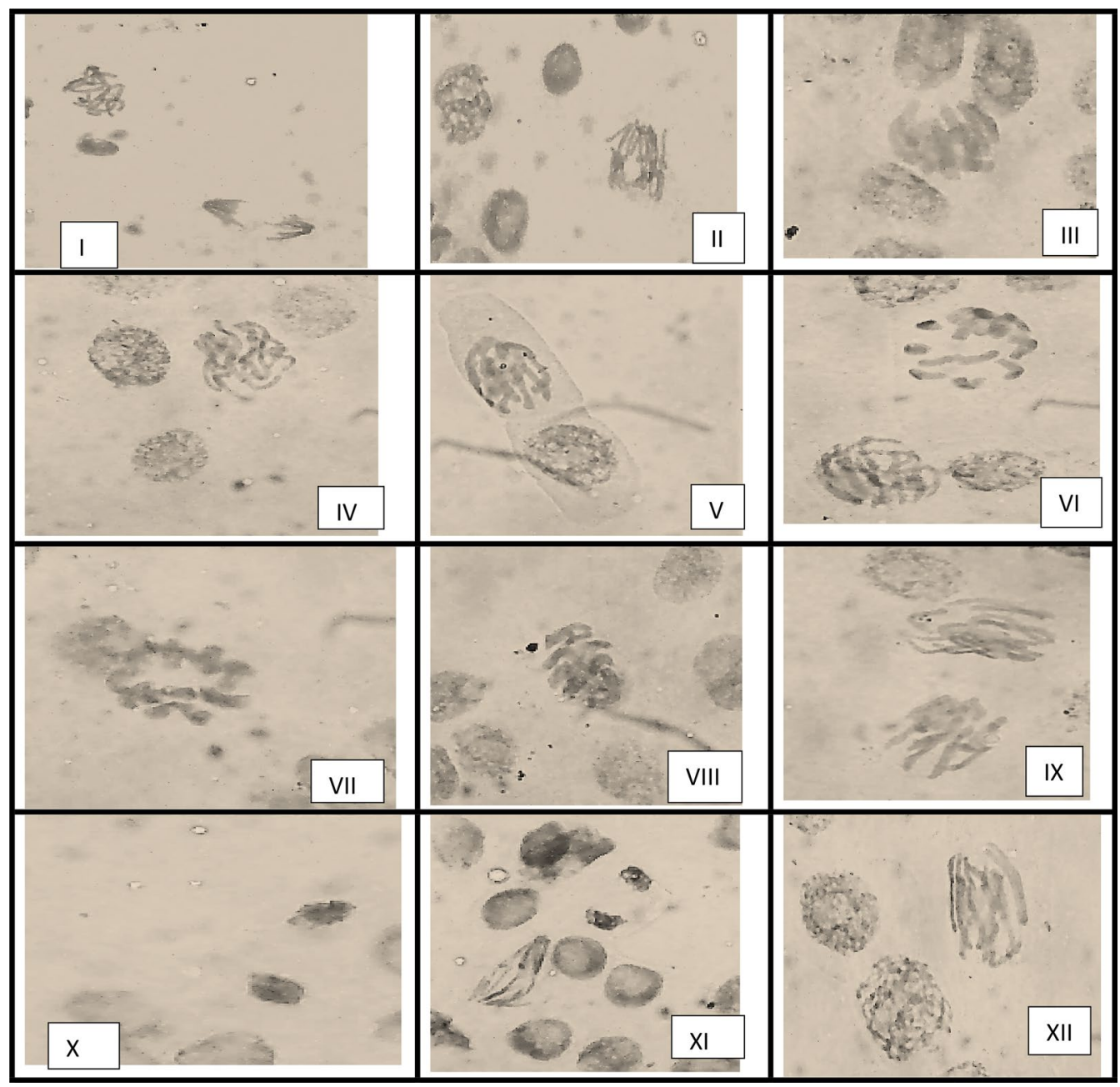

Plate $1 \mathbf{I}$-XII show the effect of $3 \mathrm{~h}$ of treatment with each of three nanostructures prepared via Gamma irradiation on Vicia faba root tip meristems. I-IV: Vicia faba root tip meristems after $3 \mathrm{~h}$ of treatment with PVP $+\mathrm{ZnSO}_{4}$ : disturbed anaphase after treatment with $1 \%(\mathbf{I})$, disturbed anaphase with sticky ended chromosomes after treatment with $2 \%$ of nano $\mathrm{ZnO}$ (II), clumped metaphase after treatment with $1 \%$ of nano ZnO (III) and disturbed prophase after treatment with $0.5 \%$ (IV). V-VIII: Vicia faba root tip meristems after 3 h of treatment with $\mathrm{PVP}^{+} \mathrm{glycerol}+\mathrm{H}_{3} \mathrm{PO}_{4}$ : disturbed prophase after treatment with $2 \%$ of nano $\mathrm{P}(\mathbf{V})$, disturbed metaphase with sticky and contracted chromosome after treatment with $2 \%$ of nano P (VI), pro-metaphase after treatment with 1\% (VII) and Sticky metaphase after treatment with $1 \%$ of nano P (VIII). IX-XII: Vicia faba root tip meristems after $3 \mathrm{~h}$ of treatment with $\mathrm{PVP}+\mathrm{Glycerol}+\mathrm{ZnSO}_{4}+\mathrm{H}_{3} \mathrm{PO}_{4}$ : disturbed prophase, sticky pro-metaphase after treatment with $2 \%$ $(\mathbf{I X})$, sticky telophase after treatment with $1 \%(\mathbf{X})$, sticky anaphase, anaphase with structural bridges after treatment with $0.5 \%(\mathbf{X I})$ and disturbed prophase after treatment with $0.5 \%$ (XII)

hydrogen molecule [Eqs. 4, 5]. Equation (6) represents the crosslinking of $\mathrm{PVP}$ by ${ }^{\circ} \mathrm{OH}$ radicals.

$$
\begin{aligned}
& \mathrm{H}_{2} \mathrm{O}+\gamma \rightarrow \text { eaq }^{-}+\bullet \mathrm{OH}+\mathrm{H}^{\bullet}+\mathrm{H}_{3} \mathrm{O}+\mathrm{H}_{2}+\mathrm{H}_{2} \mathrm{O}_{2} \\
& \text { macromolecule }+{ }^{\bullet} \mathrm{OH} \rightarrow \text { macromolecule } \\
& \text { macromolecule }+\mathrm{H}_{2} \mathrm{O}
\end{aligned}
$$

$$
\begin{aligned}
& \text { monomer }+^{\bullet} \mathrm{OH} \rightarrow \text { monomer } \\
& + \text { monomer }+\mathrm{H}_{2} \mathrm{O} \rightarrow \text { macromolecule }
\end{aligned}
$$

monomer $+\mathrm{H}^{\bullet} \rightarrow$ monomer

+ monomer $+\mathrm{H}_{2} \rightarrow$ macromolecule

$\mathrm{PVP}(\mathrm{H})+\bullet \mathrm{OH} \rightarrow \mathrm{PVP}^{\bullet}+\mathrm{H}_{2} \mathrm{O}$ 
In agree with Koczkur [19], the ZnO NPs are prepared frome $\mathrm{ZnSO}_{4}$ successfully and when coated with PVP will increase its solubility in water or any other solvents in a way that increase its cytotoxicity.

The previous studies on NPs declares that, its effect on plant cells is completely depend on the particles size and duration time of treatment. They also classify their effects into direct or indirect effect. The direct effect take place when the very small sized NPs pass through the cell membrane, diffuse through the nuclear membrane and interact directly with the chromosomes' or chromatids' DNA depend on the phase of cell cycle [39]. While the indirect effect take place when the NPs interact with protein instead of DNA or with overproduction of ROS [40].

The three prepared NPs showed their mito-accelerating effects if compared with control; this acceleration was lowered gradually with the concentration increase in case of $\mathrm{ZnO}$ NPs and exacerbated with concentration rising in case of P NPs. The mito-acceleration was recorded previously; when Citrus medica (L.) fruit extract-mediated copper nanoparticles were examined for their cyto-toxicity and genotoxicity in Allium cepa [20].

In contradict; many studies on nano-particles showed a mito-depressive effect [21, 41, 42]; this contradiction may be referred to the way of interaction of the nanoparticles, its concentration and duration time of treatment.

The three preparations induced different types of chromosome aberrations belong to different classes of abnormalities turbogenic, clastogenic and chromotoxic.

The three nano preparations affected the chromosome mobility in cell cytoplasm; induced disturbances, prometaphases and clumped chromosomes which may be explained by indirect effect on microtubules that constitute the spindle fibers or the effect on centrioles and associated protein [43].

The chromo-toxic effects which comes in second place may have resulted from the change in the chromatin material viscosity leads to physical adhesion between chromosomes [37]. Clastogenicity came in the last place which means the three forms couldn't penetrate to or affect the protein backbone of the chromosomes [38, 44].

In summary, data revealed nano $\mathrm{Zn}$ fertilizer has mito-accelerating effect but lower concentration is more preferable, while the nano-P fertilizer has a concentration dependent mito-accelerating effect on mitosis. In addition, nano-Zn product showed its effect on spindle mechanism or chromosomes mobility more than $\mathrm{P}$ product did. In opposite; $\mathrm{P}$ products showed their effect on chromosomes structure and integrity more than $\mathrm{Zn}$ products did, as they induced higher percentage of structural aberrations.

Worth to mention that; the $\mathrm{Zn} / \mathrm{P}$ mixtures product enhance the mitosis division, as it modifies the action on chromosome behavior more than each product separately do.

All in all, the treated plants can complete its division cycle to reach the final mitotic stages without cell death which indicates that the examined products in determined concentrations may have genotoxic effect but not cytotoxic effect.

\section{Conclusion}

The cytogenetic investigation here represents nontoxic and eco-friendly approach for obtaining zinc nanoparticles as a fertilizer with minimum risk of cytotoxicity and mutagenicity. The influence of zinc nanoparticles on cytological changes in actively dividing cells of Vicia faba root meristems was investigated, and we conclude that lower concentrations of zinc oxide nanoparticles exert mito-accelerating effect on root meristematic cells. However, concentration-dependent genotoxicity was also evident. Zinc oxide nanoparticle-induced decline in mitotic index was found to be associated with significant decrease in abnormality index. Mitotic abnormalities, such as chromosomal disturbance in orientation, laggards, bridges, and stickiness were observed. The study suggests that, although the usage of low concentration of zinc nanoparticles gave us hope for its non-toxicity, further studies are required for their genetically as well as environmentally safe and nontoxic applications.

Also, despite that, the usage of P NPs enhances the mitotic index; it enlarges the chromosomes abnormality happening. Based on that it is recommended to use it in low concentration to minimize its harm effect on the chromosomes.

Mixing the two NPs, shows an intermediating cytogenetic effect on mitosis apparatus of Vicia faba plant.

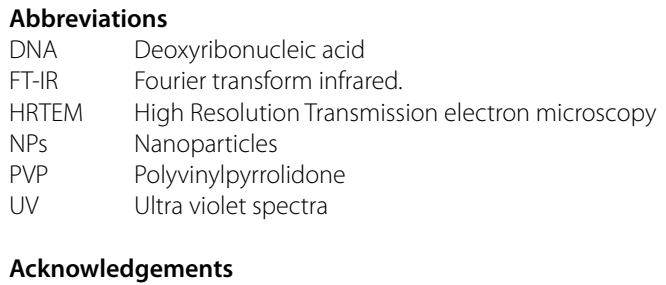

Funding

Funded by authors. 
Availability of data and materials

Not applicable.

\section{Declarations}

\section{Ethics approval and consent to participate}

Not applicable.

\section{Consent for publication}

Not applicable.

\section{Competing interests}

The authors declare that they have no competing interests.

\section{Author details}

'Radiation Research of Polymer Chemistry Department, Industrial Irradiation Division, National Center for Radiation Research and Technology, Egyptian Atomic Energy Authority, P.O. Box 9621, Nasr City 11787, Cairo, Egypt. ${ }^{2}$ Genetics \& Cytology Department, Biotechnology Research Institute, National Research Centre, Dokii, Egypt.

\section{Received: 5 October 2021 Accepted: 13 December 2021}

Published: 12 January 2022

\section{References}

1. Prasad AS. Discovery of human zinc deficiency: its impact on human health and disease. Adv Nutr. 2013;4(2):176-90. https://doi.org/10.3945/ an. 112.003210

2. Myers SS, Wessells KR, Kloog I, Zanobetti A, Schwartz J. Effect of increased concentrations of atmospheric carbon dioxide on the global threat of zinc deficiency: a modelling study. www.lancet.com/lancetgh. Published online July 16, 2015. Doi: https://doi.org/10.1016/S2214-109X(15)00093-5.

3. Chen XP, Zhang YQ, Tong YP, Xue YF, Liu DY, Zhang W. Harvesting more grain zinc of wheat for human health. Sci Rep. 2017;7:7016. https://doi. org/10.1038/s41598-017-07484-2.

4. Das S, Green A. Importance of zinc in crops and human health. J. SAT Agric. Res. 2013; 11:1-7. http://ejournal.icrisat.org/Volume11/Agroecosys tems/Importance_SDas.pdf

5. Zhang HM, Zhang YQ. Melatonin: a well-documented antioxidant with conditional pro-oxidant actions. J Pineal Res. 2014;57:131-46.

6. van Vuuren DP, Riahi K. The relationship between short-term emissions and long-term concentration targets-a letter. Clim Change. 2011;104(3):793-801.

7. Liu R, Rattan L. Synthetic apatite nanoparticles as a phosphorus fertilizer for soybean (Glycine max). Sci Rep. 2014;4:5686. https://doi.org/10.1038/ srep05686.

8. Begum P, Ikhtiari R, Fugetsu B, Matsuoka M, Akasaka T, Watari F. Phytotoxicity of multi-walled carbon nanotubes assessed by selected plant species in the seedling stage. Appl Surf Sci. 2012;262:120-4.

9. Manjunatha SB, Biradar DP, Aladakatti YR. Nanotechnology and its applications in agriculture. J farm Sci 2016; 29: 1-13. Syst 44: 257-99

10. DeRosa MC, Monreal C, Schnitzer M, Walsh R, Sultan Y. Nanotechnology in fertilizers. Nat Nano technol. 2010;5(2):91. https://doi.org/10.1038/nnano. 2010.2 .

11. Sun L, Song F, Guo J, Zhu X, Liu S, Liu F, Li X. Nano-ZnO-induced drought tolerance is associated with melatonin synthesis and metabolism in maize. Int J Mol Sci. 2020;21:782

12. Chen C, Unrine JM, Judy JD, Lewis RW, Guo J, McNear DH, Tsyusko OV. Toxicogenomic responses of the model legume Medicago truncatula to aged biosolids containing a mixture of nanomaterials $\left(\mathrm{TiO}_{2}, \mathrm{Ag}\right.$, and $\mathrm{ZnO}$ ) from a pilot wastewater treatment plant. Environ Sci Technol. 2015:49:8759-68

13. Ismail GSM, Ali AS, Eldebawy EMS, Saber NE. Role of cellular NADP+/ NADPH ratio in the acclimative mechanism of two common bean cultivars toward salt stress. J Appl Bot Food Qual. 2017;90:43-51.

14. Gupta N, Upadhyaya CP, Singh A, Abd-El-salam KA, Prasad R. Applications of silver nanoparticles in plant protection. In: Abd-El-salam K, Prasad
R, editors. Nanobiotechnology applications in plant protection. Cham: Springer International Publishing AG; 2018. p. 247-66.

15. Hu YH, Burghaus U, Qiao S. Nanotechnology for sustainable energy, ACS symposium series 1140. Washington DC: American Chemical Society; 2014

16. Mukherjee A, Peralta-Videa JR, Bandyopadhyay S, Rico CM, Zhao L, Gardea-Torresdey JL. Physiological effects of nanoparticulate $\mathrm{ZnO}$ in green peas (Pisum sativum L.) cultivated in soil. Metallomics. 2014;6:1328. https://doi.org/10.1039/c3mt00064h.

17. Takalani C. Preparation of nanoparticles, engineered nanomaterialshealth and safety, Sorin Marius Avramescu, Kalsoom Akhtar, Irina Fierascu, Sher Bahadar Khan, Fayaz Ali and Abdullah M. Asiri, IntechOpen; 2020. Doi: https://doi.org/10.5772/intechopen.90771. https:/www.intechopen. com/books/engineered-nanomaterials-health-and-safety/preparation-ofnanoparticles.

18. Flores-Rojas GG, López-Saucedo F, Bucio E. Gamma-irradiation applied in the synthesis of metallic and organic nanoparticles: a short review. Radiat Phys Chem. 2018;169:107962.

19. Koczkura KM, Mourdikoudisb SC, Lakshminarayana PE, Skrabalaka SE. Polyvinylpyrrolidone (PVP) in nanoparticle synthesis. Dalton Trans. 2015;41:17883-905

20. Nagaonkar D, Shende S, Rai M. Biosynthesis of copper nanoparticles and its effect on actively dividing cells of mitosis in Allium cepa. Biotechnol Prog. 2015;31(2):557-65.

21. Raskar SV, Laware SL. Effect of zinc oxide nanoparticles on cytology and seed germination in onion. Int J Curr Microbiol App Sci. 2014;3(2):467-73.

22. Kouhi M, Lahouti SM, Ganjeali A, Entezari MH. Long-term exposure of rapeseed (Brassica napus L.) to ZnO nanoparticles: anatomical and ultrastructural responses. Environ Sci Pollut Res. 2015:22:10733-43.

23. Hamed NA, Salah M, Ahmed F, Shoala T. Physiological assessment of radiation and PVP/ Zn- nanoparticles on sour orange seedling. Asian J Agric Hortic Res. 2019;4(4):1-18

24. Helmy KG, Partila AM, Salah M. Gamma radiation and polyvinyl pyrrolidone mediated synthesis of zinc oxide/zinc sulfide nanoparticles and evaluation of their antifungal effect on pre and post harvested orange and pomegranate fruits. Biocatal Agric Biotechnol. 2020;29:1-12.

25. Sharma AK, Sharma A. Chromosome techniques theory and practice. 3rd ed. Butterworth and Co. Publishers Itd.; 1980. p. 145-50.

26. Taiwo W, Olasunkanmi LO, Fayemi OE, Solomon MM, Ebenso EE. Zinc oxide nanocomposites of selected polymers: synthesis, characterization, and corrosion inhibition studies on mild steel in $\mathrm{HCl}$ solution. ACS Omega. 2017:2:8421-37. https://doi.org/10.1021/acsomega.7b01385.

27. Raut RW, Lakkakula JR, Kolekar NS, Mendhulkar VD, Kashid SB. Phytosynthesis of silver nanoparticle using Gliricidia sepium (Jacq.). Curr Nanosci. 2010;5:117-22.

28. Selvi J, Parthasarathy V, Mahalakshmi S, Anbarasan R, Daramola MO, Kumar PS. Optical, electrical, mechanical, and thermal properties and non-isothermal decomposition behavior of poly (vinyl alcohol)ZnO nanocomposites. Iran Polym J. 2020. https://doi.org/10.1007/ s13726-020-00806-8.

29. Singh R, Kumar N, Malhotra A. Professor, E. Dept, Int. J. Sci. Emerg. Technol. with Latest Trends 2012:4:49-53.

30. Yin S, Li S, Xie F, Zhang L, Peng J Study on the aqueous solution behavior and extraction mechanism of $\mathrm{Nd}(\mathrm{III})$ in the presence of the complexing agent lactic acid with di-(2-ethylhexyl) phosphoric acid. RSC Adv. 2015;5:64550.

31. Soltani N, Saion E, Erfani M, Rezaee K, Bahmanrokh G, Drummen GPC, Bahrami A, Hussein MZ. Influence of the polyvinyl pyrrolidone concentration on particle size and dispersion of ZnS nanoparticles synthesized by microwave irradiation. Int J Mol Sci. 2012:13:12412-27.

32. Safo IA, Werheid M, Dosche C, Oezaslan M. The role of polyvinylpyrrolidone (PVP) as a capping and structure-directing agent in the formation of Pt nanocubes. Nanoscale Adv. 2019;1:3095.

33. Jabbarnia A, Asmatulu R. Synthesis and characterization of PVdF/PVPbased electrospun membranes as separators for supercapacitor applications. J Mater Sci Technol Res. 2015:2:43-51.

34. Gadano A, Gurni A, Lopez P, Ferraro G, Carballo M. In vitro genotoxic evaluation of the medicinal plant Chenopodium ambrosioides L. J Ethnopharmacol. 2002:81:11-6. 
35. Babu K, Deepa MA, Gokul Shankar S, Rai S. Effect of nano-silver on cell division and mitotic chromosomes: a prefatory siren. Int J Nanotechnol. 2008;2:2.

36. Masarovičová E, Králová K. Essential elements and toxic metals in some crops, medicinal plants, and trees. In: Phytoremediation. 2017. p. 183-255

37. Patil $\mathrm{BC}, \mathrm{Bhat} \mathrm{Gl}$. A comparative study of $\mathrm{MH}$ and $\mathrm{EMS}$ in the induction of chromosome aberration on lateral root meristem in Clitoriaternatea L. Cytologia. 1992;57:259-64.

38. Raun C, Lian J, Luim J. Application of micreonucles test in Vicia feba root tips in the rapid detection of mutagenic environmental pollutants. Chin J Environ Sci. 1992;4:56-8.

39. Wang Y, Xie S, Liu J, Park J, Huang CZ, Xia Y. Nano Lett. 2013;13:2276.

40. Kumari M, Khan SS, Pakrashi S, Mukherjee A, Chandrasekaran N. Cytogenetic and genotoxic effects of zinc oxide nanoparticles on root cells of Allium cepa. J Hazard Mater. 2011;190:613-21.

41. Patlolla AK, Berry A, May L, Tchounwou PB. Genotoxicity of silver nanoparticles in Vicia faba: a pilot study on the environmental monitoring of nanoparticles. Int J Environ Res Public Health. 2012;9(5):1649-62.

42. Abou-Zeid HM, Moustafa Y. Physiological and cytogenetic response of wheat and barley to silver nanopriming treatment. Int J Appl Biol Pharm Technol. 2014;5:265-78.

43. Magdolenova Z, Collins A, Kumar A, Dhawan A, Stone V, Dusinska M. Mechanisms of genotoxicity A review of in vitro and in vivo studies with engineered nanoparticles. Nanotoxicology. 2014;8(3):233-78. https://doi. org/10.3109/17435390.2013.773464.

44. Haliem AS. Cytological effect of herbicide sensor on mitosis of Allium cepa. Egypt J Bot. 1990;33:93-104.

\section{Publisher's Note}

Springer Nature remains neutral with regard to jurisdictional claims in published maps and institutional affiliations.

\section{Submit your manuscript to a SpringerOpen ${ }^{\circ}$ journal and benefit from:}

- Convenient online submission

- Rigorous peer review

- Open access: articles freely available online

- High visibility within the field

- Retaining the copyright to your article

Submit your next manuscript at $\boldsymbol{\nabla}$ springeropen.com 